\author{
Maciej Szczepaniak \\ Uniwersytet im. Adama Mickiewicza w Poznaniu \\ ORCID: 0000-0002-5042-0586
}

\title{
Wiralizacja i wirtualizacja liturgii? Studium przypadku transmisji Mszy św. w czasie pandemii
}

\begin{abstract}
Abstrakt: Pandemia koronawirusa wywarła ogromny wpływ na życie wielu społeczeństw. Ograniczenia dotknęły również liturgii - źródła, z którego wypływa moc Kościoła. W wielu miejscach świata dostęp do tego źródła został ograniczony lub wręcz zagrodzony przez obostrzenia władz cywilnych.

Wydawane przez biskupów zalecenia zawierały często propozycję, aby parafie ze swoich świątyń transmitowały w mediach społecznościowych niedzielną Mszę św. Niniejsze studium przypadku jednej polskiej diecezji (poznańskiej) pokazuje skalę zjawiska transmisji. Duża ich liczba, nawet z małych parafii, świadczy o potrzebie identyfikacji wiernych z własną parafią. Autor przekonuje, że Kościół umiał zareagować na sytuację kryzysową, dokonując swoistej „rewizji” duszpasterskiej. Jego zdaniem konieczna jest jednak formacja odbiorców, by zażegnać niebezpieczeństwo wiralizacji i wirtualizacji liturgii.
\end{abstract}

Słowa kluczowe: transmisje Mszy św., wirtualność, wiralność, media społecznościowe, archidiecezja poznańska

\section{Wstęp}

Tockdown - termin na określenie dotkliwych ograniczeń dotyczących podróżowania, interakcji społecznych i dostępu do przestrzeni publicznej, został ogłoszony przez leksykografów słownika Collinsa słowem roku $2020^{1}$. Miliardy ludzi na całym świecie doznały lockdownu i wyrażały to doświadczenie, używając anglojęzycznego

1 „Lockdown - the imposition of stringent restrictions on travel, social interaction, and access to public spaces", The Collins Word of the Year 2020, https:// www.collinsdictionary.com/woty (dostęp 11.11.2020). 
terminu. Wspomniane ograniczenia dotknęły również liturgii - źródła, z którego wypływa cała moc Kościoła ${ }^{2}$. W wielu miejscach świata dostęp do tego źródła został ograniczony lub wręcz zagrodzony przez obostrzenia władz cywilnych.

Do zaistniałej sytuacji w swoich wystąpieniach odniósł się m.in. papież Franciszek. W oktawie Wielkanocy 2020 r. przestrzegał przed niebezpieczeństwem ,wiralizacji” sakramentów poprzez uczestnictwo w nich jedynie za pośrednictwem transmisji: „Proszę uważać, żeby nie wiralizować Kościoła, żeby nie wiralizować sakramentów, żeby nie wiralizować Ludu Bożego. [...] To prawda, że w tej chwili musimy przeżywać tę zażyłość z Panem w taki sposób, ale po to, żeby wyjść z tunelu, żeby w nim nie zostać"3.

Niniejsza przestroga pozwala postawić pytanie, czy rzeczywiście w czasie pandemii koronawirusa powszechnym zjawiskiem stały się transmisje Mszy św. w internecie, nawet z małych lokalnych wspólnot parafialnych, a jeśli tak - to na jaką skalę. Interesująca wydaje się też kwestia, czy ich organizatorzy traktowali je jako zjawisko trwałe, czy jedynie ,,po to, żeby wyjść z tunelu”? Celem zaproponowanego tutaj studium przypadku jednej polskiej diecezji - na gruncie metodologii teologii praktycznej - jest odpowiedź na powyższe pytania, a w dalszej perspektywie - refleksja nad zjawiskiem i niebezpieczeństwem wiralizacji i wirtualizacji liturgii.

Użyty przez papieża neologizm wiralizacja - viralizzare - pochodzi od przymiotnika virale (wirusowy), i podobnie jak jego angielski odpowiednik viralize określa wirusowe, czyli szybkie, powszechne rozprzestrzenianie się treści w internecie, zwłaszcza w mediach społecznościowych; w ten sposób na skutek kopiowania, modyfikowania i rozpowszechniania przez użytkowników słowo, obraz, dźwięk, film - zyskuje globalny rozgłos ${ }^{4}$. Z kolei terminem wirtualizacja określamy przenoszenie treści do rzeczywistości cyfrowej i sfery przeżyć zapośredniczonych przez wielopostaciowe i wielokanałowe media.

Pytanie o zjawisko wiralizacji i wirtualizacji odnosimy do liturgii, którą rozumiemy jako kościelną celebrację chrześcijańskiego

2 Sobór Watykański II, Sacrosanctum concilium, 10.

3 Franciszek, „Homilia podczas porannej Mszy św.”, 24.

4 G. Adamo, V. Della Valle, Neologismi, 757. 
misterium, wykonywanie kapłańskiego urzędu Jezusa Chrystusa. W niej przez znaki widzialne wyraża się, i w sposób właściwy poszczególnym znakom urzeczywistnia, uświęcenie człowieka (nurt zstępujący), a mistyczne Ciało Jezusa Chrystusa, to jest Głowa ze swymi członkami, wykonuje całkowity kult publiczny (nurt wstępujący) $)^{5}$.

\section{Studium przypadku}

\subsection{Metodologia badań}

Kontekstem badań empirycznych był stan zagrożenia epidemicznego spowodowany globalnym rozprzestrzenianiem się koronawirusa SARS-CoV-2 wywołującego chorobę COVID-19, oraz wprowadzone przez władze cywilne obostrzenia. Badania dotyczyły jednej polskiej diecezji - archidiecezji poznańskiej-i zostały przeprowadzone w dniach od 6 do 12 października 2020 r. Pytania badawcze skoncentrowane były na tzw. pierwszej fali epidemii, kiedy to w obiektach kultu religijnego w Polsce mogło przebywać od pięciu do pięćdziesięciu osób ${ }^{6}$.

Badanie zrealizowano za pomocą narzędzi charakterystycznych dla nauk o komunikacji. Kwestionariusz ankiety sondażowej rozesłano pocztą elektroniczną. W instrukcji wprowadzającej wyjaśniono

5 Sobór Watykański II, Sacrosanctum concilium, 7; B. Nadolski, Leksykon liturgii, 754.

6 Od 14 marca 2020 r. władze państwowe ograniczyły liczbę uczestników liturgii do 50 osób, od 25 marca do Świętego Triduum Paschalnego włącznie - do 5 osób, od 12 kwietnia (Wielkanoc) - ponownie do 50 osób, a od 20 kwietnia wprowadzono limit 1 osoby na $15 \mathrm{~m}^{2}$ powierzchni; restrykcje zniesiono 29 maja 2020 r., Rozporządzenie Ministra Zdrowia z dnia 13 marca 2020 r., http://isap.sejm. gov.pl/isap.nsf/DocDetails.xsp?id=WDU20200000433; Rozporządzenie Ministra Zdrowia z dnia 24 marca 2020 r., http://isap.sejm.gov.pl/isap.nsf/DocDetails. xsp?id=WDU20200000522; Rozporządzenie Rady Ministrów z dnia 10 kwietnia 2020 r., http://isap.sejm.gov.pl/isap.nsf/DocDetails.xsp?id=WDU20200000658; Rozporządzenie Rady Ministrów z dnia 19 kwietnia 2020 r., http://isap.sejm.gov.pl/ isap.nsf/DocDetails.xsp?id=WDU20200000697; Rozporządzenie Rady Ministrów z dnia 29 maja 2020 r. w sprawie ustanowienia określonych ograniczeń, nakazów i zakazów w związku z wystąpieniem stanu epidemii, http://isap.sejm.gov.pl/isap. nsf/DocDetails.xsp?id=WDU20200000964 (dostęp 20.11.2020). 
respondentom, że wyniki badań posłużą wyłącznie do celów naukowych, a udzielone odpowiedzi pozostaną jedynie do wiadomości ankieterów. Kwestionariusz zawierał pytania zamknięte. Dane zgromadzono w odpowiednio zaprojektowanej bazie, a następnie opracowano je za pomocą pakietu programu do obróbki badań statystycznych.

Pytania badawcze, które postawiono przed przygotowaniem kwestionariusza ankiety, dotyczyły liczby parafii dysponujących stałymi transmisjami liturgii Mszy św. przed pandemią, realizacji postulatu pastoralnego transmisji podczas pandemii oraz zamierzeń w tym względzie po jej ustaniu. Celem badań była także odpowiedź na pytanie, czy czas obostrzeń sanitarnych przyczynił się do zwiększenia potencjału parafialnych profili społecznościowych.

W drugim etapie badań każdy z respondentów mógł skorzystać z możliwości wyrażenia własnej opinii na temat transmisji liturgii. Zarówno badania ilościowe, jak i opinie respondentów posłużyły do sformułowania wniosków i postulatów pastoralnych.

\subsection{Badania ilościowe}

Kwestionariusz ankiety na temat transmisji liturgii Mszy św. został rozesłany do wszystkich proboszczów w diecezji w liczbie 393, zarządzających 414 parafiami ${ }^{7}$. Na ankietę odpowiedzieli wszyscy adresaci ${ }^{8}$. Wybrana do badań empirycznych grupa badawcza stanowi zatem całą populację - są to duchowni, którzy zgodnie z Kodeksem prawa kanonicznego (KPK kan. 523) zostali mianowani przez biskupa diecezjalnego proboszczami parafii należących do wybranej diecezji ${ }^{9}$. Ponieważ ,„parafia jest określoną wspólnotą wiernych,

7 W dalszej części nazwę ,,parafia” stosuje się w znaczeniu ,parafia lub parafie zarządzane przez jednego proboszcza"; n=393.

8 Respondenci, którzy nie odpowiedzieli na ankietę za pomocą poczty elektronicznej, zostali poproszeni przez ankieterów o jej wypełnienie telefonicznie.

9 Dekrety nominacyjne w archidiecezji poznańskiej zawierają następujące określenie zadań proboszczów: „Swoje obowiązki Ksiądz Proboszcz będzie wypełniał jako pasterz zatroskany o powierzoną Mu wspólnotę - zgodnie z odnośnymi przepisami prawa kanonicznego i archidiecezjalnego prawa partykularnego - pamiętając, że wykonuje zadania nauczania, uświęcania i kierowania Ludem 
utworzoną na sposób stały w Kościele partykularnym, nad którą pasterską pieczę, pod władzą biskupa diecezjalnego, powierza się proboszczowi jako jej własnemu pasterzowi” (KPK kan. 515 §1), założono, że odpowiedzi udzielane przez proboszcza będą w pełni miarodajne.

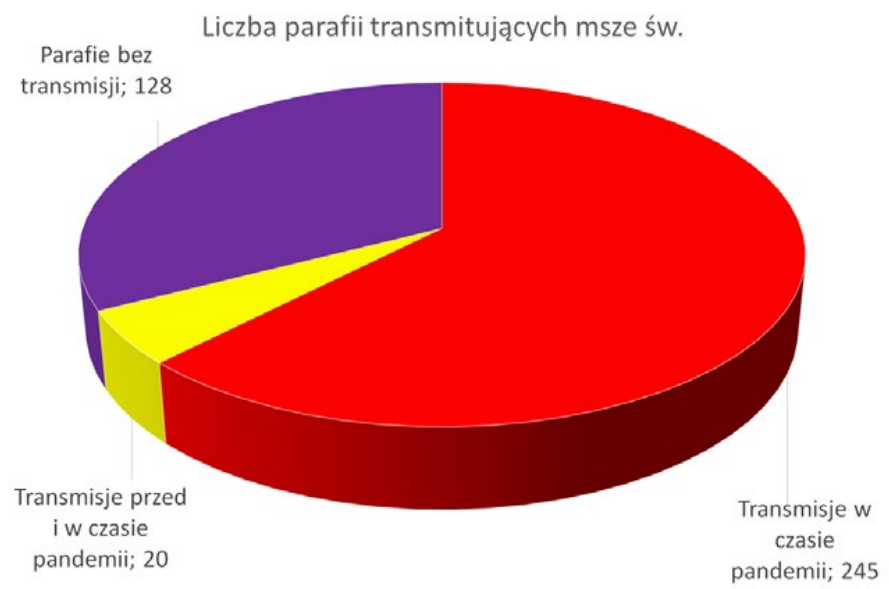

Wykres 1: Liczba parafii archidiecezji poznańskiej transmitujących liturgię Mszy św. przed i w czasie pandemii

Z przeprowadzonych badań wynika, że jedynie z 20 kościołów archidiecezji poznańskiej transmitowano Msze św. przed pandemią, co stanowi 5\% ogólnej liczby parafii. 245 kolejnych wspólnot parafialnych podjęło transmisje po wybuchu pandemii w marcu 2020 r., a 128 nie zdecydowało się na rozpoczęcie transmisji w czasie ograniczeń spowodowanych zagrożeniem epidemicznym. Warto wspomnieć, że miejscowy biskup diecezjalny zachęcał proboszczów do podjęcia transmisji niedzielnej Mszy św. z homilią ${ }^{10}$.

Bożym, powołany do uczestnictwa w posłudze samego Chrystusa (por. Christus Dominus, 30, kan. 519 KPK, statuty 88-117 Synodu Archidiecezji Poznańskiej, Status proboszcza w Archidiecezji Poznańskiej)".

10 W dekrecie abp. Stanisława Gądeckiego czytamy: „Zalecam też, aby parafie ze swoich świątyń - w miarę możliwości technicznych - transmitowały w mediach społecznościowych niedzielną Mszę św. z homilią duszpasterza, jak również codzienną wieczorną modlitwę różańcową”, „Dekret arcybiskupa poznańskiego po wprowadzeniu stanu zagrożenia epidemicznego w Polsce z 13 marca 2020 r.”, 172. 
Jedna trzecia parafii $(128$, czyli $32,6 \%, n=393)$ poprzestała zatem na liturgii celebrowanej dla wąskiego grona wiernych, którzy mogli przebywać w świątyni. W większości nie posiadały też one mediów społecznościowych i nie utworzyły takich profili podczas epidemii (108, czyli 85\%, n=128). Zdecydowana większość wspólnot parafialnych bez transmisji to parafie wiejskie lub podmiejskie od 1 do 3 tys. mieszkańców (86 parafii, czyli 67\%, $\mathrm{n}=128$ ); w dalszej kolejności: parafie poniżej 1 tys. mieszkańców $(23$, czyli 18\%, $n=128)$, parafie liczące od 3 do 6 tys. mieszkańców (13, czyli 10\%, n=128), parafie liczące od 6 do 10 tys. mieszkańców $(5$, czyli 4\%, n=128) oraz jedna typowo miejska duża parafia powyżej 10 tys. mieszkańców. Parafie nieprowadzące transmisji były zarządzane przez proboszczów relatywnie młodych. Wśród kapłanów, którzy nie zdecydowali się na transmisje liturgii, aż $31 \%$ było poniżej 50 . roku życia (40 proboszczów). Dalsze 37\% respondentów było w przedziale wiekowym od 50. do 60 . roku życia (47 proboszczów), 24\% pomiędzy 60. a 70. rokiem życia (31 proboszczów), 8\% powyżej 70. roku życia (10 proboszczów).

Jak wspomnieliśmy, 265 parafii transmitowało liturgię Mszy św. w czasie pandemii, przy czym 20 z nich transmitowało ją już wcześniej. Tylko 46 parafii $(17 \%, n=265)$ zdecydowało się na całodobową transmisję wnętrza kościoła, z czego $30 \mathrm{z}$ nich zainstalowało konieczne urządzenia dopiero w czasie pandemii. Wśród parafii transmitujących liturgię nie brakowało małych wspólnot - 111 z nich nie miało więcej niż 3 tys. mieszkańców $(42 \%, n=265)$.

Administratorzy parafii transmitowali Msze św. przede wszystkim na fanpage'u Facebooka (128 parafii) oraz w portalu YouTube (102

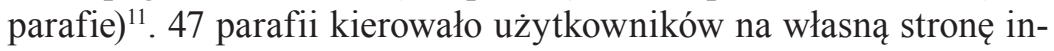
ternetową, gdzie zainstalowano odpowiednią aplikację do odbierania transmisji. Większość proboszczów $(163$, czyli 61,5\%, n=265)

11 Do zwiększenia popularności portalu YouTube z pewnością przyczyniło się zniesienie przez firmę Google warunku posiadania 1000 subskrybentów do przeprowadzania transmisji na żywo. Mogły z tej propozycji skorzystać parafie, które wyraziły chęć transmitowania liturgii w portalu YouTube w czasie pandemii. Uruchomiono specjalny adres poczty elektronicznej dla zainteresowanych (parafie. zwolnienie@gmail.com). Google prowadziło też dla chętnych parafii bezpłatne szkolenia z przeprowadzania transmisji, ,,Google ułatwia parafiom transmisje”, https:// episkopat.pl/google-ulatwia-parafiom-transmisje-na-youtube/ (dostęp 20.11.2020). 
podjęła decyzję o przerwaniu transmisji Mszy św. w internecie po zniesieniu obostrzeń epidemicznych w maju 2020 r. W 102 parafiach $(38,5 \%, n=265)$ kontynuowano transmisje wszystkich bądź wybranych celebracji liturgicznych. Jeszcze większy odsetek proboszczów zadeklarował, że po ustaniu pandemii koronawirusa na pewno nie będzie transmitować liturgii w internecie (177 parafii, czyli 67\%, $\mathrm{n}=265)$. Wliczając $\mathrm{w}$ to duszpasterzy, którzy nie podjęli transmisji, daje to odsetek bliski $80 \%$ księży dystansujących się od transmitowania liturgii Mszy św. z własnej parafii (305 parafii, czyli 78\%, $\mathrm{n}=393)$. W diecezji 63 proboszczów zadeklarowało chęć dalszego przeprowadzania transmisji, 25 księży nie miało na ten temat wyrobionej opinii. Liczba zdecydowanych zwolenników transmisji wzrosła zatem przez pandemię z 20 do 63. Są to przede wszystkim administratorzy większych parafii: $80 \%$ z nich liczy powyżej trzech tysięcy mieszkańców (do 1 tys. $-1,1-3$ tys. $-11,3-6$ tys. $-26,6-10$ tys. -16 , powyżej 10 tys. -9$)$.

\section{Po pandemii w parafii:}

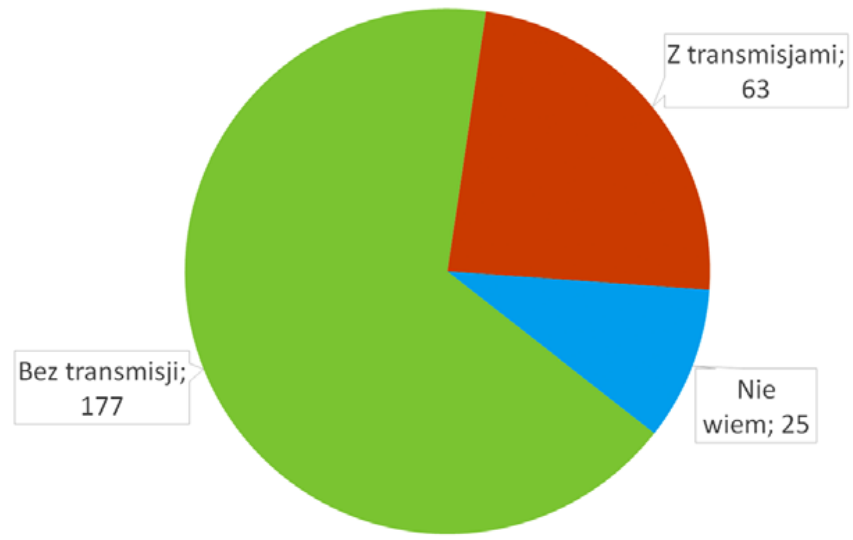

Wykres 2: Deklaracje na temat kontynuowania transmisji liturgii Mszy św. po ustaniu pandemii w archidiecezji poznańskiej

Kwestionariusz ankiety rozesłanej do parafii zawierał także pytanie o wykorzystanie mediów społecznościowych podczas pandemii dla celów duszpasterskich. Jedynie 54\% księży (213 parafii, $\mathrm{n}=393)$ zauważyło potrzebę aktywności w parafialnych mediach społecznościowych, takich jak Facebook, Twitter, Instagram. Wśród 
nieaktywnej w social mediach grupy jest stosunkowo duży odsetek relatywnie młodych kapłanów - 26\% z nich nie ukończyło jeszcze 50. roku życia (grupa wiekowa 30-40 lat - 1 proboszcz; 40-50 lat - 46 księży; 50-60 lat - 70 księży; 60-70 lat - 47 księży; powyżej 70 lat - 16 księży).

\subsection{Opinie badanych na temat transmisji liturgii}

Ankieta sondażowa oprócz pytań zamkniętych zawierała także rubrykę, w której respondenci mogli wyrazić swoją opinię na temat transmisji liturgii za pomocą nowych technologii medialnych. W wypowiedziach proboszczów i parafian często pojawiały się dwie myśli: z jednej strony nowe technologie cyfrowe nie zastąpią bezpośredniego kontaktu ze wspólnotą parafialną uczestniczącą w kościelnej celebracji chrześcijańskiego misterium, z drugiej zaś - są pomocną formą ewangelizacji, a w sytuacji nadzwyczajnej stanowią pomoc w duchowej formacji i dają łączność z liturgią celebrowaną w świątyni.

\subsubsection{Użyteczność}

Odbiorcy ankiety byli zgodni, że w sytuacji ograniczenia liczby uczestników liturgii podczas pandemii koronawirusa transmisje z kościołów parafialnych były użyteczne, przydatne. Twierdzili, że był to ,jedyny sposób" na kontakt parafian ze swoim kościołem i że „większość parafian” uczestniczyła we Mszy św. dzięki transmisji. Podkreślano, że odbywały się one na prośbę wiernych, którzy wyrażali za nie wdzięczność. Zauważano, że codzienna transmisja liturgii Mszy św. sprawiła, że parafianie nie czuli się opuszczeni w tym trudnym czasie. Jako szczególnych odbiorców przekazu wskazywano chorych na COVID-19, osoby w kwarantannie, starszych, mieszkańców domów opieki społecznej, a nawet parafian mieszkających za granicą.

Uczestnicy badania zauważali także, że społecznościowy charakter mediów to dobry sposób dotarcia do ludzi młodych. Pomaga on też w integracji parafian, a możliwość ,,zdalnego uczestnictwa w liturgii własnej wspólnoty" stawała się także okazją do formacji. „Korzystanie z mediów może tylko zwiększyć zasięg działania 
parafii" - pisał jeden z proboszczów. Ważnym wątkiem wypowiedzi respondentów było zwrócenie uwagi na wysokie wymagania odbiorców co do jakości transmisji. Proboszczowie czuli się zobligowani do zamontowania profesjonalnego sprzętu i zwiększenia mocy sieci komputerowej.

\subsubsection{Uczestnictwo}

Respondenci dostrzegali w transmisjach wydarzenie, w którym wierni rzeczywiście partycypowali. W wypowiedziach znajdujemy określenia wskazujące na poczucie czynnego uczestnictwa: „udział” w parafialnej Mszy św., ,,przeżywanie” Eucharystii ze swojego kościoła parafialnego, ,przebywanie” w świątyni, modlenie się razem $\mathrm{z}$ innymi, patrzenie na ołtarz. Jeden z proboszczów opisał celebrację uroczystości wielkanocnej połączonej z udzieleniem Komunii św.: „Po Mszy św. transmitowanej przez YouTube wyjechałem z Komunią św. do parafian. Zgodnie z tym, co przekazałem w czasie transmisji, parafianie stali w furtkach swoich posiadłości i cierpliwie czekali, aż podjadę, potem podchodzili do samochodu i przyjmowali Komunię św. Cała «akcja» zajęła ok. 40 minut, ponieważ parafia jest malutka, ale doświadczenie było bardzo mocne".

W wypowiedziach pojawiał się też wątek pomocy udzielanej przez ludzi młodych swoim dziadkom czy rodzicom w obsłudze urządzeń pozwalających na oglądanie liturgii - komputerów czy smartfonów. Niektórzy wskazywali jednak na fakt, że urządzenia nowych technologii, w przeciwieństwie do radia czy telewizji, nie sprzyjają wspólnotowemu przeżywaniu liturgii: każdy z członków rodziny oglądał transmisje na ekranie samodzielnie, zamknięty w swoim pokoju.

\subsubsection{Między powrotem do Eucharystii a rozleniwieniem}

W wypowiedziach respondentów często pojawiał się też wątek świadomości parafian, że transmisja nie zastąpi im nigdy rzeczywistego udziału w liturgii. Podkreślano, że po ustaniu obostrzeń wielu wiernych wróciło do praktykowania uczestnictwa w Eucharystii. Zauważano, że tylko „liturgia w kościele jest dla nich żywa i autentyczna”.

Byli także respondenci, którzy odnotowali ,rozleniwienie” niektórych parafian i fakt, że nie wszyscy powrócili do ,realnych praktyk". Pisano, że transmisje Mszy św. skutecznie odciągnęły ludzi od 
kościoła i sakramentów, „oziębiły” wewnętrzną potrzebę rzeczywistego uczestnictwa i fizycznej obecności w kościele parafialnym.

\section{Liturgia zapośredniczona przez nowe media}

\subsection{Wiralizacja liturgii}

Każda epoka niesie za sobą rozwój sposobów przekazu społecznego, który dotyka także życia religijnego. Czas pandemii koronawirusa pokazał, że Kościół umie reagować na zmiany, dokonując swoistej „rewizji” duszpasterskiej. Podczas obostrzeń sanitarnych powszechnym - i nowym na taką skalę, jak wynika z przeprowadzonego studium przypadku - zjawiskiem stały się parafialne transmisje liturgii Eucharystii za pośrednictwem internetu, głównie w mediach społecznościowych. Duża liczba transmisji, nawet z małych parafii, pokazała, że wierni odczuwają potrzebę identyfikacji z własną wspólnotą, a duszpasterze potrafią odpowiedzieć na to zapotrzebowanie. Pomimo że transmitowanie parafialnej Mszy św. zapewne nie zawsze spełniało wymóg wzorcowego przygotowania i celebracji liturgii, doboru śpiewów i opracowania homilii, duszpasterze zauważali konieczność sprostania wymaganiom medialnej realizacji. W kontekście pewnej „konkurencyjności”, starali się dostosować przekaz do wirtualnej i wiralnej rzeczywistości, co wyrażało się choćby w zakupie i używaniu profesjonalnego sprzętu czy dostosowaniu łączy internetowych do potrzeb transmisji. Z podobnym zjawiskiem duszpasterskiej „rewizji” w sytuacji nadzwyczajnej mieliśmy do czynienia - w odniesieniu do środków przekazu - w początkach teologicznej debaty na temat transmisji liturgii. Pius XI, z zasady przeciwny transmisjom, zaaprobował je podczas wojny domowej w Hiszpanii w 1938 r. ${ }^{12}$

12 Dziennik L’Osservatore Romano pisał wówczas: „[...] Ojciec Święty nadał katolikom zamieszkałym na terenie podlegającym rządowi w Barcelonie nadzwyczajny przywilej «ważnego wysłuchania» Mszy św. celebrowanej i transmitowanej z siedziby «Radio Nacional» w Salamance. Warto wyjaśnić, że Ojciec Święty ograniczył się do zezwolenia na odprawianie Mszy św. w specjalnym pomieszczeniu przeznaczonym wyłącznie na kaplicę w siedzibie «Radia Nacional» w Salamance, aby można było przeprowadzić transmisje radiowe ku pocieszeniu i duchowemu 
Czy masowy streaming liturgii zaszkodził Kościołowi i przyczynił się do przeżywania religii jedynie online? We wspomnianej homilii wygłoszonej w 2020 r. podczas Mszy św. transmitowanej także w internecie, papież Franciszek przestrzegał przed niebezpieczeństwem ,wiralizacji” Kościoła, sakramentów, Ludu Bożego: „Proszę uważać, żeby nie wiralizować Kościoła, żeby nie wiralizować sakramentów, żeby nie wiralizować Ludu Bożego [non viralizzare la Chiesa, [...] i sacramenti, [...] il popolo di Dio]. Kościół, sakramenty, Lud Boży są konkretne. To prawda, że w tej chwili musimy przeżywać tę zażyłość z Panem w taki sposób, ale po to, żeby wyjść z tunelu, żeby w nim nie zostać. [...] Oby Pan nauczył nas tej bliskości z Nim, tej zażyłości z Nim, ale w Kościele, z sakramentami, ze świętym wiernym Ludem Bożym"13. Otwarte pozostaje pytanie, czy Franciszek miał na myśli wiralizację, czyli wirusowe, szybkie i powszechne rozprzestrzenianie się treści w internecie, czy może także wirtualizację Kościoła, sakramentów, Ludu Bożego. Powyższą wątpliwość potwierdza oficjalny przekład powyższego tekstu na język angielski, w którym anglicyzm virale tłumaczy się przez virtual (wirtualny), zachowując oryginalne brzmienie słowa jedynie jako tło wypowiedzi ${ }^{14}$. Mielibyśmy wówczas przede wszystkim monit przed

pożytkowi wielu wiernych, którzy w obecnych bolesnych okolicznościach nie mogą chodzić do kościoła. [...]”, „La Santa Messa e la radio”, 4.

13 Franciszek, „Homilia podczas porannej Mszy św.”, 24; http://www.vatican. $\mathrm{va} /$ content/francesco/it/cotidie/2020/documents/papa-francesco-cotidie_20200417 lafamiliarita-conil-signore.html (dostęp 20.11.2020).

14 „Be careful not to make the Church virtual, viral; not to make the sacraments virtual, not to make the people of God virtual. The Church, the sacraments, the people of God are concrete. It is true that in this moment we must provide this familiarity with God in this way, but so as to come out of the tunnel, not to stay inside it", http://www.vatican.va/content/francesco/en/cotidie/2020/documents/papa-francesco-cotidie_20200417_lafamiliarita-conil-signore.html (dostęp 20.11.2020). Pozostałe wersje językowe trzymają się użytego neologizmu (fr. viraliser, hiszp. i port. viralizar, niem. viralisieren). Tłumacz na j. niem. uważał jednak za stosowne dodać wyjaśnienie terminu (,Von «viral», das zwei Bedeutungen haben kann: «durch ein Virus verursacht», aber auch: «besonders durch Kontakte in den sozialen Medien schnell weite Verbreitung im Internet findend»", http://www.vatican.va/ content/francesco/de/cotidie/2020/documents/papa-francesco-cotidie_20200417_ lafamiliarita-conil-signore.html) (dostęp 20.11.2020). 
przenoszeniem treści do sfery przeżyć zapośredniczonych przez wielopostaciowe i wielokanałowe media, a co za tym idzie, traktowania ich jako rzeczywistości wykreowanej na ekranie komputera czy nawet stworzonej jedynie w ludzkim umyśle.

Jakie zagrożenia niesie za sobą ,wiralna” transmisja liturgii? Zjawisko powszechnej medialnej dystrybucji treści religijnych samo w sobie nie jest niczym złym. Skupienie się na przepływie, strumieniach, linkach, swoistym chaosie cybernetycznym, zanurzenie w cyfrowej i złożonej rzeczywistości medialnej jest kontekstem ewangelizacji, a więc także liturgii. Ale ,zakotwiczenie” transmisji liturgii w społecznościowym chaosie informacji, stwarza poważne niebezpieczeństwo traktowania jej jako wydarzenia, które się ,przegląda" na ekranie tabletu czy komputera, bez poczucia uczestnictwa w akcie kultu. Ekran jest już nie tylko medium - pośrednikiem między twórcą przekazu a jego odbiorcą, jak w przypadku telewizyjnego ekranu czy głośnika radia. Ekran komputera czy telefonu staje się multimedialnym narzędziem, rozszerzeniem naszych zmysłów na świat, używając kategorii McLuhanowskich. Potrzeba więc dużo samodyscypliny, żeby medialną reprezentację zanurzoną w cyfrowej rzeczywistości odnieść do konkretnego wydarzenia, przy którym odbiorca nie manipuluje, i ,być” - jedynie i aż-duchowo w świątyni, w której celebruje się liturgię. To zagrożenie potwierdzają analizy transmisji parafialnych Mszy św. na portalach społecznościowych: retencja odbiorców transmisji na Facebooku i YouTube z dużej miejskiej parafii wskazuje, że w czasie rzeczywistym film oglądały równocześnie maksymalnie 23 osoby; z kolei nieco ponad 300 odbiorców filmu przestało go oglądać po upływie 2 minut.

Transmisje umieszczone na kanałach społecznościowych jako content do ponownego oglądnięcia wykraczają poza tradycyjne rozumienie celów pastoralnych związanych z liturgią przekazywaną w środkach społecznego przekazu. Transmisja nie jest już tylko obrazem i dźwiękiem zmieniającym się w czasie, ale filmem, który może zostać zatrzymany i ponownie odtworzony, przesłany innym użytkownikom, czy nawet zmodyfikowany. Czy jest to kierunek nieodwracalny? Chyba tak. Nie brakuje głosów zachęcających do 
transmitowania Mszy św. jedynie w czasie rzeczywistym ${ }^{15}$, których najbardziej skuteczną realizacją wydaje się być stała transmisja wnętrza świątyni. Badania pokazują jednak, że na takie rozwiązanie zdecydowała się stosunkowo mała liczba parafii. Specyfika mediów społecznościowych, w których umieszcza się film z nagraniem sprawia, że transmisje zazwyczaj pozostają w sieci jako obraz do ponownego odtworzenia. Kłóci się to w oczywisty sposób z niepowtarzalnością liturgii.

Wątpliwości budzić może także społecznościowy kontekst transmisji, poddanej mechanizmom wiralności. Pojawiające się w tle komentarze i polubienia mogą stać się wyrazem dominacji wymiaru emotywnego w kształtowaniu własnej religijności. „Polubienie” celebrowanej liturgii może być wprawdzie postrzegane w kategoriach komunikatu zwrotnego pod adresem kaznodziei czy celebransa, który pomógł nam zbliżyć się do Boga, a głoszone przez niego treści przepowiadania spotkały się z naszym zainteresowaniem. Kryje w sobie jednak niebezpieczeństwo wartościowania celebrowanej liturgii pod kątem polubień i uśmiechów. Nie bez znaczenia dla moralnej oceny zjawiska wiralności pozostaje także praktyczna nieusuwalność treści umieszczonych w internecie. Zjawisko oceniane negatywnie w kontekście przemocy w sieci, agresji, dręczenia, zawstydzania czy wykluczenia społecznego, dotyka w naszym przypadku prywatności uczestników liturgii, którzy zostają sfilmowani podczas aktu religijnego przeżywanego często w intymnej sferze życia wewnętrznego podczas modlitwy czy przyjmowania Komunii św. ${ }^{16}$

15 Np. ze strony Kościelnego Inspektora Ochrony Danych przy Konferencji Episkopatu Polski: „Należy preferować transmisje jedynie na żywo, czyli przekazywanie obrazu i dźwięku w czasie rzeczywistym. Nie zaleca się umieszczania w internecie do późniejszego odtworzenia nagrań całych Mszy św.”, „Uwagi KIOD nt. weryfikacji tożsamości i transmisji Mszy św.”, 88. „Transmitowanie Mszy św. i nabożeństw domaga się wzorcowego przygotowania i celebracji liturgii, doboru śpiewów, opracowania homilii czy katechezy. Celebracje powinny być transmitowane jedynie w czasie rzeczywistym, dlatego nie należy udostępniać nagrań obrzędów Mszy św. po ich zakończeniu, z wyjątkiem liturgii słowa”, „Dekret arcybiskupa poznańskiego dotyczący duszpasterstwa w czasie epidemii”, 284.

16 Cytowany wcześniej okólnik podpisany przez ks. Piotra Kroczka zawiera monit: „W trakcie transmisji lub nagrywania takich Mszy św. zasadniczo trzeba unikać pokazywania wizerunków wiernych w takich szczególnych sytuacjach, jak 


\subsection{Wirtualizacja liturgii}

Zjawisko transmisji liturgii dotyka z pewnością kwestii naruszenia jej misteryjności i sakralności. Zagadnienie to jest nieobce myśli teologicznej od momentu pojawienia się radia ${ }^{17}$. Przypomnijmy, że w wielu krajach początkowo unikano transmitowania liturgii Mszy św. - we Francji, w Niemczech czy we Włoszech preferowano jedynie transmisje kazań. Wyraźnym głosem sprzeciwu było stanowisko katolickich biskupów niemieckich z 1926 r., którzy zalecili dystans wobec transmisji ze względu na disciplina sacra $^{18}$. Niedługo potem Pius XI, w odpowiedzi na pytanie abp. Pragi Františka Kordača w tej kwestii zaaprobował rozstrzygnięcie Kongregacji Świętego Oficjum non expedire - nie jest pożyteczne, stwierdzając: ,nie można na to pozwolić dla żadnego powodu"19; jego opinia była cytowana w urzędowych pismach ${ }^{20}$, w mediach ${ }^{21}$, w dyskursie teologicznym ${ }^{22}$. Te początkowe wątpliwości nie zatrzymały zjawiska, które - z punktu widzenia pastoralnego - niosło za sobą wiele dobra, zwłaszcza wobec ludzi chorych i cierpiących. Akceptacja transmisji nie mogła jednak powstrzymać wyrażania obaw przed rezygnacją z uczestnictwa w liturgii na rzecz jej medialnej reprodukcji ${ }^{23}$.

np. przyjmowanie Komunii św. Najlepiej, gdy kamera jest skierowana wyłącznie na celebransa. [...] Nigdy nie wolno bezprawnie naruszać prawa wiernych do ochrony własnej prywatności i należy uszanować chęć jej zachowania także podczas transmisji lub nagrywania Mszy św.”, „Uwagi KIOD nt. weryfikacji tożsamości i transmisji Mszy św.", 87-88.

17 A. Draguła, Eucharystia zmediatyzowana, 30-38; M. Szczepaniak, Msza fonogeniczna, 40-48.

18 „Protokoll der Fuldaer Bischofskonferenz”, 4a, 10.08.1926, 747; „Sermons et offices reproduits par T. S. F.", 1108.

19 Archivio della Congregazione per la Dottrina della Fede, Dubbia Varia 1927, n. 1 , prot. 90/1927, 2, 10 .

${ }^{20}$ „Cantum liturgicum per macchinam «radio» divulgare non expedit“, 48-49; „Zákaz wysílati z kostela církecní hudbu radiem”, 207.

${ }^{21}$ Depeszę Associated Press przedrukowano m.in. w: „Broadcasting of Singing at High Masses Forbidden", 1.

${ }^{22}$ L. David, „Liturgie et radiophonie”, 197-203; V. Facchinetti, La radio e l'apostolato religioso, 87.

$23 \mathrm{~Np}$. „Nawet w najlepszym wypadku przekaz radiowy jest tylko surogatem, czyli zamiennikiem bezpośredniego i osobistego oddziaływania duchowego człowieka na człowieka”, A. Rüegg, „Katholisches Leben und Radio”, 82; „Byłoby to 
Niebezpieczeństwo wirtualizacji liturgii polega na zaprzestaniu prowadzenia człowieka do przeżywania sakramentów jako znaku „zażyłości” z Bogiem i pozostawieniu go jedynie w świecie cyfrowych mediów. Nie chodzi tu jedynie o oczywistą kwestię niemożności przyjęcia Komunii św. Zgoda na uczestnictwo w liturgii transmitowanej w internecie może prowadzić do budowania kultury efemeryczności i oddalenia od realnej wspólnoty. Jak słusznie zauważał L. David w odniesieniu do pierwszych radiowych Mszy św., „,transmisja na nieokreśloną odległość zniekształca i tak jakby nie uznaje tego podstawowego charakteru modlitwy liturgicznej, eucharystycznej, ofiarnej, «lokalnej», jak i jej bliskiego, koniecznego związku z odczuwalnym aktem ofiary oraz realnym uczestnictwem wiernych" ${ }^{24}$. Stąd też trzeba przypominać, że: „Rzeczywistość wirtualna nie jest zamiennikiem Realnej Obecności Chrystusa w Eucharystii, sakramentalnej rzeczywistości innych sakramentów i współudziału w kulcie sprawowanym w żywej wspólnocie. W internecie nie ma sakramentów; a nawet doświadczenia religijne, możliwe w nim dzięki łasce Boga nie są wystarczające w oderwaniu od współdziałania $\mathrm{z}$ innymi wiernymi w świecie rzeczywistym"25. Przypomnienie to jest potrzebne, ponieważ nowe technologie medialne pozwalają nie tylko oglądać film z wnętrza kościoła, ale zanurzyć się w wirtualnej rzeczywistości religijnej dając odczucie jej autentyczności, realności, fizyczności ${ }^{26}$. $\mathrm{Z}$ drugiej jednak strony powyższe studium przypadku pokazało, że duża liczba transmisji z małych parafii była odpowiedzią na szukanie kontaktu z własną - a więc realną, żywą - wspólnotą kościelną.

Transmisja liturgii dociera do odbiorcy znajdującego się fizycznie poza wspólnotą celebrującą misterium Jezusa Chrystusa - zapośredniczone przez media oglądanie i przysłuchiwanie się wydarzeniu stawia go bardziej w roli ,widza” niż „uczestnika”. Jak słusznie

smutnym objawem, gdyby wierni więcej sobie cenili Mszę Ojca Świętego, transmitowaną przez radio, niż Mszę, na której mogą być obecni w swoim kościele", M. Pirożyński, „Duchowieństwo wobec radia”, 33.

24 L. David, „Liturgie et radiophonie”, 199.

25 Papieska Rada ds. Środków Społecznego Przekazu, Kościół a Internet, 22.02.2002, https://opoka.org.pl/biblioteka/W/WR/rady_pontyfikalne/r_komunik_spol/kosciol_internet_22022002.html (dostęp 20.11.2020).

${ }_{26}$ A. Spadaro, ,«Second life». Il desiderio di un'«altra vita»”, 273. 
zauważa Karl Rahner, z antropologicznego punktu widzenia kamera nie ma tych samych praw, co zmysły człowieka uczestniczącego w liturgii i przeżywającego ją w postawie intymności ${ }^{27}$. Na korzyść transmisji internetowych przemawia jednak ich „naturalność”, brak wyreżyserowanych kadrów i ciągłej zmiany planów. Oko kamery zwrócone jest zazwyczaj na celebransa i ołtarz, w przeciwieństwie do telewizji nikt nie kreuje znaczeń poprzez sekwencję rozmaitych ujęć filmowych, ogólnych czy szczegółowych, jakbyśmy byli w ciągłym ruchu przechadzając się po wnętrzu świątyni. W tym znaczeniu transmisja internetowa - podobnie jak audycja radiowa $\mathrm{z}$ jej foniczną przestrzenią - bardziej przypomina realny sposób udziału wiernych w Eucharystii niż transmisja telewizyjna.

Czy używanie w odniesieniu do liturgii transmitowanej przez media słowa „uczestnictwo” jest uzasadnione? Benedykt XVI w adhortacji apostolskiej Sacramentum caritatis zwrócił uwagę na fakt, że ,ze względu na niebywały rozwój środków przekazu [...] słowo «uczestnictwo» nabyło szerszego znaczenia niż w przeszłości”28. Soborowe spojrzenie na participatio w liturgii zakładało uczestnictwo świadome, czynne i owocne ${ }^{29}$. Ważnym wyrazem uczestnictwa czynnego są zapewne gesty, postawa ciała czy wypowiadane słowa, świadectwo wiary dawane wobec wspólnoty Kościoła. Zapewne pozostanie otwarte pytanie: Czy uczestnictwo „zdalne” w wydarzeniach, które stało się jednym z przejawów życia społecznego w czasie pandemii - i może jednym z najtrwalszych jej skutków - może być „czynne” w teologicznym tego słowa znaczeniu? W dużej mierze participatio actuosa opiera się jednak na wewnętrznym zjednoczeniu z Chrystusem, a przykłady z przeszłości, jak opowiadanie o św. Klarze przypomniane przez Piusa XII w kontekście medialnym $^{30}$, pozostawiają nadzieję na przyjęcie przez człowieka - także

27 K. Rahner, Die Messe und das Fernsehen, 33-34.

28 Benedykt XVI, Sacramentum caritatis, 57.

29 Sobór Watykański II, Sacrosanctum concilium, 11.

30 „Na patronkę telewizji została przedstawiona św. Klara, która - jak głosi tradycja - pewnej nocy w święto Bożego Narodzenia, leżąc chora w swoim klasztorze w Asyżu usłyszała pobożne pienia rozbrzmiewające w świątyni franciszkańskiej podczas świętych obrzędów i zobaczyła żłóbek Bożego Dzieciątka, jakby była przy tym obecna. Niech więc Klara, jaśniejąca chwałą dziewictwa i w tak wielkich 
w ten sposób - daru Boga i w pełni aktywną odpowiedź całej osoby ludzkiej. Niektórzy zauważają zresztą, że każde przeżycie duchowe, także modlitwa, nosi w sobie pewien rys ,wirtualności” - człowiek „słucha” Boga, „rozmawia” z Nim, a doświadczenie Jego obecności przekracza ramy naszej fizyczności, angażuje naszą wyobraźnię ${ }^{31}$. Jeśli przyznamy rację stwierdzeniu, że dziś wszystko jest medialne, nawet kultura podlega procesowi wirtualizacji, a sygnały wysłane w cyberprzestrzeń nie tylko zastępują język naturalny, ale są wyrazem nadziei na spotkanie ${ }^{32}$, zrozumiemy, że świat mediów - który jest bez wątpienia światem człowieka oraz integralną częścią współczesnej kultury - może mieć też punkty styczne z liturgią i może starać się ją przekazać za pomocą języka, którym dysponuje ${ }^{33}$.

Potrzebna jest zatem formacja, która pozwoli potencjalnym „uczestnikom” cyfrowej transmisji lepiej pojmować sens udziału w Eucharystii, odchodząc od jej jurydycznego kontekstu (praeceptum dominicale) i dążąc do przeżywania sakramentu jako mistagogicznej rzeczywistości. Doświadczenie pandemii koronawirusa pokazało bowiem, że rozporządzenia władz cywilnych ograniczające możliwość rzeczywistego udziału w liturgii skutkowały przede wszystkim natychmiastowymi reakcjami biskupów udzielających dyspensy, czyli zwolnienia od obowiązku uczestnictwa we Mszy św. niedzielnej i świątecznej (KPK kan. 1247) ${ }^{34}$. W sytuacji obostrzeń duszpasterze - bardziej niż na akcentowaniu zwolnienia z obowiązku uczestnictwa i zachęty do odsłuchiwania bądź oglądania transmisji Mszy św. - powinni byli skupić się na wyjaśnieniu, ,,jak uczestniczyć

ciemnościach emanująca niebiańskim światłem stoi na czele tego wynalazku i niech sprawi, aby za jego pośrednictwem zajaśniała prawda i cnota, na których winien opierać się porządek społeczny”, Pius XII, Clarius explendescit.

31 L. Voltolin, „L'immaginario della liturgia e i new media”, 30.

32 W.J. Burszta, ,Wirtualizacja kultury i co z tego wynika”, 25-38.

33 C. Cibien, ,Mass media e liturgia”, 1142; M. Drożdż, „Prymat osoby w mediach", 71 .

34 „Przypominam również o dyspensie wydawanej przed biskupów diecezjalnych od obowiązku uczestnictwa w niedzielnych i świątecznych Mszach Świętych, zgodnie z Kodeksem prawa kanonicznego. Osoby, które z niej korzystają, proszę o duchową łączność ze wspólnotą Kościoła za pośrednictwem transmisji w środkach społecznego przekazu”, „Komunikat przewodniczącego KEP w związku z wprowadzeniem stanu zagrożenia epidemicznego w Polsce”, 145. 
w transmitowanej liturgii”, wskazując na potrzebę rodzinnej modlitwy i budowania Kościoła domowego ${ }^{35}$. Podobne przeakcentowanie kontekstu jurydycznego widać było zresztą w reakcjach na pierwsze radiowe transmisje liturgiczne - echem odbijało się wówczas stwierdzenie, że „obowiązkowi słuchania Mszy św. w dni świąteczne oraz w niedziele, za pośrednictwem radiofonii nie czyni się zadość"36.

\section{Zakończenie}

Statystyki wyszukiwarki internetowej Google potwierdzają, że w 2020 r. człowiek szukał przede wszystkim słów powiązanych znaczeniowo z pandemią koronawirusa, częściej niż kiedykolwiek wcześniej zadając pytanie why - dlaczego ${ }^{37}$. Podstawowe założenia dotyczące komunikacji mówią, że jest ona holistyczna, funkcjonalna i adaptacyjna. Można przez analogię powiedzieć, że w czasie pandemii były to także założenia dotyczące zorganizowanej działalności zbawczej Kościoła. Może być ona realizowana jako proces, który tworzy pewien system: zastosowanie poszczególnych etapów pozwala osiągnąć odmienny rezultat, niż pozwalają na to jego pojedyncze

35 Np. w komunikacie abp. Wiktora Skworca z marca 2020 r. zachęta do rodzinnej modlitwy poprzedzała informację o transmisjach Mszy św.: „Zapraszam wiernych do codziennej modlitwy indywidualnej i w rodzinach. Przypominam o możliwości uczestniczenia w niedzielnej Mszy św. za pośrednictwem radia lub telewizji [...], można też korzystać z transmisji internetowych Mszy św. proponowanych przez poszczególne parafie", Zalecenia szczegółowe metropolity katowickiego, https:// katowice.gosc.pl/doc/6213540.Archidiecezja-katowicka-Zalecenia-szczegolowe-w-zwiazku-z (dostęp 20.11.2020). W archidiecezji wrocławskiej w tzw. drugiej fali epidemii w październiku 2020 r. nie udzielono w ogóle dyspensy, tłumacząc w mediach społecznościowych, że opieka nad bliźnimi lub silna obawa przed zarażeniem sama z siebie usprawiedliwia nieobecność na Mszy św., https://www. facebook.com/Archidiecezja.Wroclawska (dostęp 20.11.2020).

36 Cytat pochodzi z opinii przygotowanej dla Kongregacji Świętego Oficjum, J. Hudeček, „De usu radiofoniae”, 17. Abp August Hlond po pierwszych transmisjach liturgicznych z katedry poznańskiej wydał dekret, w którym stwierdzał: „Pouczy Wielebne Duchowieństwo wiernych, że wysłuchanie tychże śpiewów i kazań nie zwalnia od obowiązku sumienia słuchania Mszy św. w kościele w niedziele i święta”, „Nadawanie do radia kazań i śpiewów liturgicznych”, 29.

37 Google - Year in Search 2020, https://about.google/stories/year-in-search-2020/ (dostęp 10.12.2020). 
elementy. Potrafi też być funkcjonalna, tzn. być wykorzystywana do osiągania preferowanych rezultatów. Jest adaptacyjna, bo prowokuje do modyfikacji naszych zachowań tak, by dostosowały się one do określonych sytuacji. Kościół - poprzez liczne transmisje liturgii z kościołów parafialnych - spróbował odpowiedzieć człowiekowi na pytania o sens zdarzeń, przybliżając mu i urzeczywistniając zbawcze dzieło Chrystusa.

Każda nowa technologia tworzy nowe przyzwyczajenia. Wobec zagrożeń wynikających $\mathrm{z}$ wiralnego i wirtualnego charakteru technologii cyfrowych potrzebujemy tego, co w dzisiejszej sytuacji medialnej nazywa się agregacją: uporządkowaniem treści i relacji, aby nie zagubić istoty liturgii - źródła, z którego wypływa moc Kościoła. To uporządkowanie musi służyć odbiorcom. Używając metafor biblijnych, chodzi o podawanie ręki w cyfrowej, a czasami nawet w epidemicznej burzy, by utrzymać właściwy kurs ku zbawieniu (Mt 14,22-33). Bardziej więc niż na zaklinaniu wiralnej i wirtualnej rzeczywistości powinno nam zależeć na przypominaniu o istocie sakramentów. W tym sensie rzeczywiście odkrywcze pozostaje przesłanie kard. Roberta Saraha: „Powróćmy do Eucharystii” ${ }^{38}$. Transmisje Mszy św. będą także w przyszłości szansą pastoralną, nie zastąpią jednak liturgii, celebracji misterium Jezusa Chrystusa, w którym przez znaki widzialne wyraża się, i w sposób właściwy poszczególnym znakom urzeczywistnia uświęcenie człowieka.

\section{Making the Liturgy Viral and Virtual? A Case Study of Holy Mass Broadcasting During the Pandemic}

Abstract: The coronavirus pandemic has had a huge impact on the lives of many
societies. Restrictions also affected the liturgy, the source from which the power of
the Church flows. From the liturgy, therefore, and especially from the Eucharist, as
from a font, grace is poured forth upon us; and the sanctification of men and women
in Christ and the glorification of God, to which all other activities of the Church are
directed as toward their end, is achieved in the most efficacious possible way. In
many parts of the world, access to this source has been limited or even barred by
restrictions of civil authorities. Recommendations issued by bishops often included
proposals for parishes to broadcast the Sunday Mass on social media. This case study
of one Polish diocese (Poznań) shows the scale of the transmission phenomenon.
The large number of broadcasts, even from small parishes, proves the need for the

38 R. Sarah, „Powróćmy z radością do Eucharystii!”, 32-34. 
faithful to identify with their own parish. The author argues that the Church has been able to respond to the crisis situation by making a kind of pastoral "revision". In his opinion, however, the formation of the recipients is necessary to avert the danger of making the Church liturgy viral and virtual.

Keywords: broadcast of the Holy Mass, virtuality, virality, social media, Poznań Archdiocese

\section{Bibliografia}

Adamo, G., Della Valle, V., Neologismi. Parole nuove dai giornali (2008-2018), Roma 2018.

Archidiecezja Wrocławska, https://www.facebook.com/Archidiecezja.Wroclawska (dostęp 20.11.2020).

Archivio della Congregazione per la Dottrina della Fede, Dubbia Varia 1927, n. 1, prot. 90/1927.

Benedykt XVI, Posynodalna adhortacja apostolska Sacramentum caritatis, L'Osservatore Romano (wyd. pol.) 28 (2007) nr 4, 4-42.

„Broadcasting of Singing at High Masses Forbidden”, The Echo [Buffalo] (31.05.1928), 1.

Burszta, W.J., „Wirtualizacja kultury i co z tego wynika”, w: M. Kempny, G. Woroniecka (red.), Religia i kultura w globalizującym się świecie, Kraków 1999, 25-38.

„Cantum liturgicum per macchinam «radio» divulgare non expedit”, Ordinariátní list Pražské arcidiecése (1928) nr 5, 48-49.

Cibien, C., „Mass media e liturgia”, w: D. Sartore, A.M. Triacca, C. Cibien, Liturgia, Milano 2001, 1134-1150.

David, L., „Liturgie et radiophonie”, La Vie Spirituelle Ascétique et Mystique 11 (1930) nr 1, 197-203.

„Dekret arcybiskupa poznańskiego dotyczący duszpasterstwa w czasie epidemii z 7 maja 2020 r.", Miesięcznik Kościelny Archidiecezji Poznańskiej $71(2020) \mathrm{nr}$ 5, 280-284.

„Dekret arcybiskupa poznańskiego po wprowadzeniu stanu zagrożenia epidemicznego w Polsce z 13 marca 2020 r.", Miesięcznik Kościelny Archidiecezji Poznańskiej 71 (2020) nr 3, 172-173.

Draguła, A., Eucharystia zmediatyzowana. Teologiczno-pastoralna interpretacja transmisji Mszy Świętej w radiu i telewizji, Zielona Góra 2009.

Drożdż, M., „Prymat osoby w mediach”, w: M. Drożdż (red.), Wolność w mediach. Między poprawnościa a odpowiedzialnościa, Tarnów 2010, 71-78.

Facchinetti, V., La radio e l'apostolato religioso, Milano 1930.

Franciszek, „Homilia podczas porannej Mszy św. w Domu Świętej Marty” (17.04.2020 r.), L'Osservatore Romano (wyd. pol.) 41 (2020) nr 6, 23-24; http://www.vatican.va/content/francesco/de/cotidie/2020/documents/ 
papa-francesco-cotidie_20200417_lafamiliarita-conil-signore.html (dostęp 1.10.2020).

Google - Year in Search 2020, https://about.google/stories/year-in-search-2020/ (dostęp 10.12.2020).

Hudeček, J., „De usu radiofoniae”, Archivio della Congregazione per la Dottrina della Fede, Dubbia Varia 1936, n. 6, prot. 760/1936, 11-21.

„Komunikat przewodniczącego KEP w związku z wprowadzeniem stanu zagrożenia epidemicznego w Polsce", Miesięcznik Kościelny Archidiecezji Poznańskiej 71 (2020) nr 3, 145.

Konferencja Episkopatu Polski, „Google ułatwia parafiom transmisje na YouTube", https://episkopat.pl/google-ulatwia-parafiom-transmisje-na-youtube/ (dostęp 20.11.2020).

„La Santa Messa e la radio”, L'Osservatore Romano 78 (1938) nr 58, 4.

„Nadawanie do radia kazań i śpiewów liturgicznych”, Miesięcznik Kościelny dla Archidiecezji Gnieźnieńskiej i Poznańskiej 42 (1927) nr 6, 29.

Nadolski, B. (oprac.), Leksykon liturgii, Poznań 2006.

Papieska Rada ds. Środków Społecznego Przekazu, Kościót a Internet, 22.02.2002, https://opoka.org.pl/biblioteka/W/WR/rady_pontyfikalne/r_komunik_spol/kosciol_internet_22022002.html (dostęp 20.11.2020).

Pirożyński, M., „Duchowieństwo wobec radia”, Homo Dei 8 (1939) nr 1, 30-37. Pius XII, breve ap. Clarius explendescit, 14.02.1958.

„Protokoll der Fuldaer Bischofskonferenz”, w: H. Hürten (red.), Akten Deutscher Bischöfe über die Lage der Kirche 1918-1933, t. 2, Paderborn-MünchenWien-Zürich 2007.

Rahner, K., Die Messe und das Fernsehen, w: R. Guardini, R. Kahlefeld, Apparatur und Glaube, Würzburg 1955, 33-47.

Rozporzadzenie Ministra Zdrowia z dnia 13 marca 2020 r. w sprawie ogłoszenia na obszarze Rzeczypospolitej Polskiej stanu zagrożenia epidemicznego, http://isap.sejm.gov.pl/isap.nsf/DocDetails.xsp?id=WDU20200000433 (dostęp 20.11.2020).

Rozporzadzenie Ministra Zdrowia z dnia 24 marca 2020 r. zmieniajace rozporzadzenie $w$ sprawie ogłoszenia na obszarze Rzeczypospolitej Polskiej stanu epidemii, http://isap.sejm.gov.pl/isap.nsf/DocDetails.xsp?id= WDU20200000522 (dostęp 20.11.2020).

Rozporzadzenie Rady Ministrów z dnia 10 kwietnia 2020 r. w sprawie ustanowienia określonych ograniczeń, nakazów i zakazów w zwiazku z wystapieniem stanu epidemii, http://isap.sejm.gov.pl/isap.nsf/DocDetails. xsp?id=WDU20200000658 (dostęp 20.11.2020).

Rozporzadzenie Rady Ministrów z dnia 19 kwietnia 2020 r. w sprawie ustanowienia określonych ograniczeń, nakazów i zakazów w zwiazku z wystapieniem stanu epidemii, http://isap.sejm.gov.pl/isap.nsf/DocDetails. xsp?id=WDU20200000697 (dostęp 20.11.2020). 
Rozporządzenie Rady Ministrów z dnia 29 maja 2020 r. w sprawie ustanowienia określonych ograniczeń, nakazów i zakazów w zwiąku z wystapieniem stanu epidemii, http://isap.sejm.gov.pl/isap.nsf/DocDetails. xsp?id=WDU20200000964 (dostęp 20.11.2020).

Rüegg, A., „Katholisches Leben und Radio”, Volksvereins Annalen. Zeitschrift für katholisches Vereinswesen 2 (1927) nr 3, 79-83.

Sarah, R., „Powróćmy z radością do Eucharystii!”, L'Osservatore Romano (wyd. pol.) 41 (2020) nr 10, 32-34.

„Sermons et offices reproduits par T. S. F., Déclaration de l'épiscopat allemand", Documentation Catholique 18 (1927), 1108.

Sobór Watykański II, Konstytucje, dekrety, deklaracje, Poznań 1967.

Spadaro, A., „«Second life». Il desiderio di un'«altra vita»”, La Civiltá Cattolica (2007) nr 3771-3772, 266-278.

Szczepaniak, M., Msza fonogeniczna. Pierwsza polska transmisja Mszy Świętej i towarzyszace jej okoliczności, Poznań 2013.

The Collins Word of the Year 2020 is LOCKDOWN, https://www.collinsdictionary.com/woty (dostęp 11.11.2020].

„Uwagi KIOD nt. weryfikacji tożsamości i transmisji Mszy św.”, Miesięcznik Kościelny Archidiecezji Poznańskiej 72 (2021) nr 2, 86-88.

Voltolin, L., „L'immaginario della liturgia e i new media”, Rivista Liturgica 107 (2020) nr 1, 17-32.

„Zákaz wysílati z kostela církecní hudbu radiem”, Ordinariátní list Litoměřrické biskupské diecese (1928) nr 56, 207.

Zalecenia szczególowe arcybiskupa katowickiego do zarzadzenia Rady Stałej KEP z dn. 12 marca br., https://katowice.gosc.pl/doc/6213540.Archidiecezja-katowicka-Zalecenia-szczegolowe-w-zwiazku-z (dostęp 20.11.2020). 